\title{
SCREENING AND BIOSYNTHESIS OF FIBRINOLYTIC ENZYME FROM ASPERGILLUS JAPONICUM
}

\author{
*Saroj Yadav ${ }^{1}$ and Siddalingeshwara K G ${ }^{2}$ \\ ${ }^{1}$ Research and Development Centre, Bharathiar University, Coimbatore, India \\ ${ }^{2}$ Scientific \& Industrial Research Centre, Bangalore, India \\ *Corresponding Author's E-mail: siddha_lingeshwar@rediffmail.com
}

Received 01 Sep 2015; Review Completed 22 Oct 2015; Accepted 27 Oct 2015, Available online 15 Nov 2015

\begin{abstract}
Fibrin is a protein that forms in the blood clots after trauma or injury. This is essential to stop blood loss. There are more than twenty enzymes in the body that assist in clotting of the blood, while only one that can break the clot down. It is an endogenously produced fibrinolytic enzyme called plasmin. Streptokinase is an extracellular metallo-enzyme produced by betahaemolytic streptococcus and is used as an effective and cheap clot-dissolving medication in some cases of myocardial infarction (heart attack) and pulmonary embolism. It belongs to a group of medications known as fibrinolytics. Fibrinolytic enzymes can be found in a variety of foods, such as Japanese Natto, Tofuyo, Korean Chungkook-Jang soy sauce, and edible honey mushroom. Fibrinolytic enzymes producing Aspergillus japonicum KSS 05 strain were screened for the production by fibrin plate assay method. The maximum zone of fibrin hydrolysis were found $6 \mathrm{~mm}$ diameter. Further the Aspergillus japonicum KSS 05 were employed for the production by submerged fermentation and it showed $235 \mathrm{IU}$ by $\mathrm{pH} 6$, temperature $30^{\circ} \mathrm{C}$ and $1 \mathrm{ml}$ inoculums size.
\end{abstract}

Key words: Fermentation kinetics, effect of $\mathrm{pH}$, fibrinolytic enzymes and fibrin

\section{INTRODUCTION:}

Fibrinolytic enzyme is well known as a sub class of protease, which has an ability to degrade fibrin ${ }^{1-3}$. Blood clots (fibrin) are formed from fibrinogen by thrombin (EC 3.4.21.5) and are lysed by plasmin (EC 3.4.21.7), which is activated from plasminogen by tissue plasminogen activator ${ }^{4}$.

Accumulation of fibrin in the blood vessels usually results in thrombosis, leading to myocardial infarction and other cardiovascular diseases 5 . These diseases are the leading causes of death throughout the world ${ }^{6}$. Thrombolytic agents convert plasminogen to plasmin, lyse the clot by breaking down the fibrin contained in a clot.

Currently fibrinolytic enzymes that dissolve blood clots and show promise for thrombosis therapy have been successfully identified from various sources. A wide range of microorganisms has been screened for their fibrinolytic properties ${ }^{7}$. Fibrinolytic enzymes have been reported from various bacterial species of Bacillus ${ }^{8}$, Staphylococcus ${ }^{9}$, Coryneform bacteria ${ }^{10}$, Pseudomonas ${ }^{11}$ and Alteromonas ${ }^{12}$. Some fungi have also been found to have high fibrinolytic activity, as Aspergillus ochraceus $513^{13}$, Fusarium sp. ${ }^{14}$, Rhizopus chinensis $12^{15}$ and Penicillium sp. ${ }^{16}$. In addition, fibrinolytic enzymes produced from different species of mushrooms $17-19$
Our aim of the present study is to screen and produce the fibrinolytic enzymes through submerged fermentation by optimizing fermentation parameters from Aspergillus japonicum.

\section{MATERIALS AND METHODS:}

\section{Experimental microorganism}

Aspergillus japonicum were isolated from soils collected from different regions in and around Bangalore. The Aspergillus japonicum were isolated by using Czapek Dox's media and tentatively identified in the laboratory and confirmed at Agharakar Research Institute, Pune.

\section{Screening of fibrinolytic enzyme by fibrin plate assay}

Fibrinolytic activity was determined using the method described by Astrup and Mullertz ${ }^{20}$. The fibrin agarose plate was made to a $1 \mathrm{~mm}$ thickness, and contained agarose $(1.2 \% \mathrm{w} / \mathrm{v})$, bovine fibrinogen $(0.4 \% \mathrm{w} / \mathrm{v})$, and bovine thrombin $(20 \mathrm{U} / \mathrm{mL})$ in a petridisc, and the clot was allowed to stand for $1 \mathrm{~h}$ at room temperature. Then, $10 \mu \mathrm{L}$ of sample enzyme solution was carefully placed onto the plate. The plate was incubated for $5 \mathrm{~h}$ at $37^{\circ} \mathrm{C}$ and the diameter of the lytic zone was measured and the clear transparent region was observed in which fibrin is 
hydrolyzed (Plate-1). This diameter is directly proportional to the strength of the fibrinolytic activity.

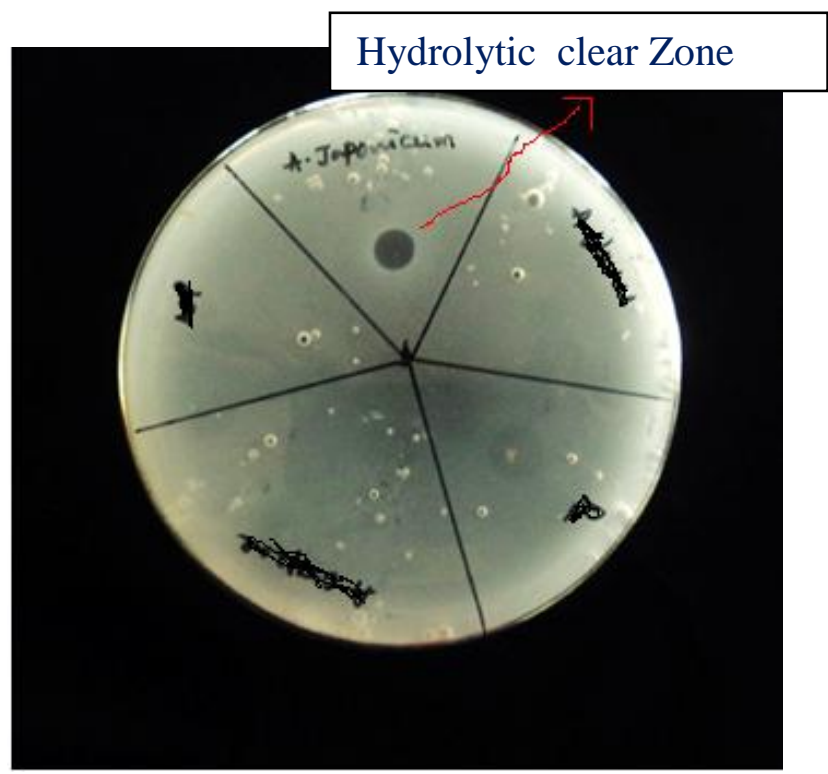

Plate-1: Fibrin plate assay by Aspergillus japonicum

\section{Production of fibrinolytic enzyme through} submerged fermentation

The isolate was grown in Czapek-Dox media: Composition (g/l) Sucrose-30.0; Sodium nitrate-2.0; K2HPO4-1.0, MgSO4. 7H2O-0.5; KCl-0.5; FeSO4-0.01 for $96-120 \mathrm{~h}$ on a shaker with constant $140 \mathrm{rpm}$. The $\mathrm{pH} 6$, temperature $30^{\circ} \mathrm{C}$ and $1 \mathrm{ml}$ inoculums size were maintained.

\section{Assay of fibrinolytic enzyme}

This was basically measured by the modified method of Anson, but with a few modifications. The reaction mixture contained $1 \mathrm{ml}$ of $1.2 \%$ of bovine fibrin solution in Tris- $\mathrm{HCl}$ buffer $(\mathrm{pH} \mathrm{8.0)}$ and $1 \mathrm{ml}$ of cellfree supernatant (CFS). The reaction mixture was incubated for $2 \mathrm{~h}$ at $37^{\circ} \mathrm{C}$. Then the reaction was stopped by the addition of $2 \mathrm{ml}$ of $10 \%$ (w/v) trichloroacetic acid. This was followed by centrifugation and assaying the solubilized proteins for tyrosine in the supernatant by measuring the absorbance at $750 \mathrm{~nm}^{21}$.

Unit: One unit of fibrinolytic activity (U) was defined as the amount of enzyme required to liberate $1 \mu \mathrm{g}$ of Ltyrosine $/ \mathrm{ml} / \mathrm{min}$ at $37^{\circ} \mathrm{C}$.

\section{RESULTS AND DISCUSSION:}

Fungal isolates were isolated from different regions from Bangalore and identified as Aspergillus japonicum in Agrakar Research Institute, Pune. All thirty strains of Aspergillus japonicum produced clear zone around colony in fibrin plate medium and Aspergillus japonicum KSS 05 showed $6 \mathrm{~mm}$ diameter of cleared zone those were selected from the soil sample. Of the thirty isolates Aspergillus japonicum KSS 05 was considered to be the best and high fibrinolytic enzyme producing strain. It showed $6 \mathrm{~mm}$ of cleared zone around the colony (Plate-1). The data obtained in the present study on the effect of $\mathrm{pH}$, temperature and inoculums size on submerged fermentation is shown in Fig.1, which reveals that the production of fibrinolytic enzyme increased with the increase in the $\mathrm{pH}$ of the medium up to $\mathrm{pH} 6.0$ temperatures $30^{\circ} \mathrm{C}$ and inoculum size $1.0 \mathrm{ml}$, for this it showed $235 \mathrm{U} / \mathrm{ml}$ thereafter the decrease of fibrinolytic activity was observed.

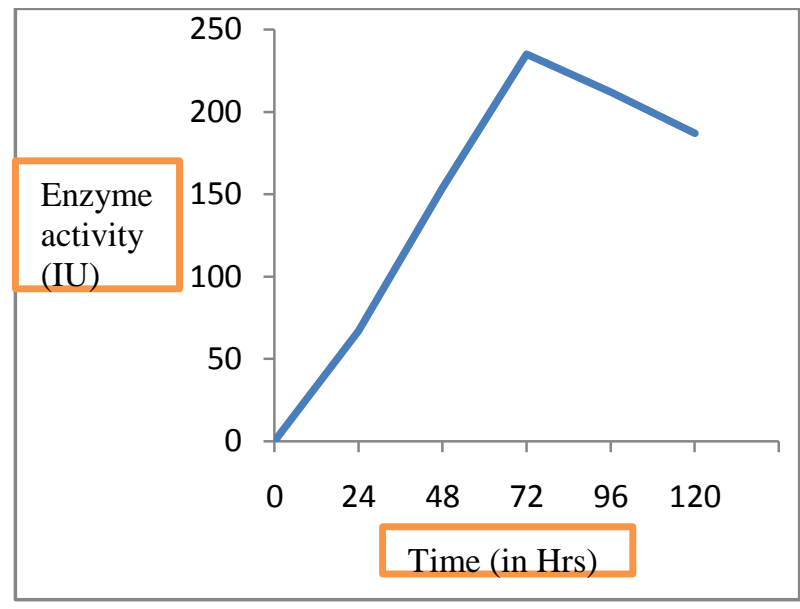

Figure 1: Production of fibrinolytic enzyme by optimized fermentation kinetics

Shilpa et al., ${ }^{22}$ were reported that production of fibrinolytic enzyme showed better activity $180 \mathrm{U} / \mathrm{ml}$ at pH 6 temperature $40^{\circ} \mathrm{C}$ and inoculum size will be 1.25 ml. Usama et al. ${ }^{23}$ showed that incubation temperature $35^{0} \mathrm{C}$ is optimum for maximum production of fibrinolytic enzyme and it showed $2.30 \mathrm{unit} / \mathrm{mg}$ protein. Keeping this in view, experiments were conducted to find out the effect of temperature on fibrinolytic enzyme production by Aspergillus japonicum KSS 05. It is generally necessary to optimize age and size of the inoculums, because low density gives insufficient biomass and high density produces too much biomass and resulting in depletion of nutrients necessary for fibrinolytic protease production. The earlier studies reported that inoculums size has crucial effect in fermentation process through microorganisms. In our studies $1.0 \mathrm{ml}$ of inoculum size were showed better yield. Venkatanagaraju and Divakar ${ }^{24}$ reported that 2 $\%$ of mutant Bacillus cereus spores as an inoculums from one week old culture were inoculated for the maximum production of fibrinolytic enzyme and our results are consistent with Venkatanagaraju and Divakar 24

\section{CONCLUSION}

Aspergillus japonicum KSS 05 were isolated from different soil samples from different regions from Karnataka and screened for the production of fibrinolytic enzyme by plate assay and also initial fermentation parameters studies were also carried out for the maximum production of fibrinolytic enzyme. 


\section{REFERENCES:}

1. Fujita M, Nomura K, Hong K, Ito Y, Asada A, Nishimuro S. Purification and character of a strong fibrinolytic enzyme (nattokinase) in the vegetable cheese natto, a popular soybean fermented food in japan. BiochemBiophys Res Commun, 1993; 197: 1340-47.

2. Jeong YK, Yang WS, Kim KH, Chung KT, Loo WH, Park JU. Purification of a fibrinolytic enzyme (myulchikinase) from pickled anchovy and its cytotoxicity to the tumer cell lines. BiotechnolLett, 2004; 26:393-97.

3. Sumi H, Nakajima N, Yatagai C. A unique strong fibrinolytic enzyme (katsuwokinase) in skipjack Shiokara a Japanese traditional fermented food. Com BiochemPhysiolBiochem MolBiol, 1995; 112:543-47.

4. Voet D, Voet JG, Charlotte W. Principles of Biochemistry. 3rd ed., Wiley, New York;2008, pp. 87-95.

5. Kim, S.H. and N.S. Choi, 2000. Purification and characterization of subtilisin DJ-4 secreted by Bacillus sp strain DJ-4 screened from Doen-Jang. Biosci. Biotechnol. Biochem., 64: 1722-1725.

6. Mine, Y., A.H.K. Wong and B. Jiang, 2005. Fibrinolytic enzymes in Asian traditional fermented foods, Food Research International, 38: 243-250.

7. Takeno, T., T. Okamura, M. Sera, M. Takana, S. Fukuda and M. Ohsugi, 1999. Screening of fibrinolytic enzymes of microorganisms. The Bulletin of Mukogawa's University Natural of Science, 47: 67-72.

8. Yu, R., H. Qi, T. Zhang and W.T. Wu, 2005. Preliminary studies on in vitro and in vivo thrombolytic activities of thrombolytic enzyme from an induced Bacillus subtilis strain. Sichuan Da Xue Xue Bao Yi Xue Ban, 36: 93-96.

9. Choi, N.S., J.J. Song, D.M. Chung, Y.J. Kim, P.J. Maeng and S.H. Kim, 2009. Purification and characterization of a novel thermoacid-stable fibrinolytic enzyme from Staphylococcus sp. strain AJ isolated from Korean salt-fermented Anchovy-joet. J. Ind. Microbiol. Biotechnol., 36: 417- 426.

10. Egorov, N.S., N.S. Landau and I.I.Milovanova, 1982. Fibrinolytic activity in mono- and mixed cultures of coryneform bacteria. Nauchnye Doki Vyss Shkoly Biol Nauki, 10: 86-90.

11. Imshenetskii, A.A., N.S. Demina, S.V. Lysenko and M.D. Evdokimova, 1991. Fibrinolytic activity of bacteria from Pseudomonas genus. Prikl. Biokhim. Mikrobiol., 27: 845-849.

12. Demina, N.S., F. Veslopolova and G.P. Gaenko, 1990. The marine bacterium Alteromonas piscicida-a producer of enzymes with thrombolytic action. Izv. Akad. Nauk. SSSR Biol., 3: 415419.

13. Batomunkueva, B.P. and N.S. Egorov, 2001. Isolation, purification and resolution of the extracellular proteinase complex of Aspergillus ochraceus 513 with fibrinolytic and anticoagulant activities. Microbiology, 70: 519-522.

14. Wu, B., L. Wu, D. Chen, Z. Yang and M. Luo, 2009. Purification and characterization of a novel fibrinolytic protease from Fusarium sp. CPCC 480097. J. Ind. Microbiol. Biotechnol., 36: 451-459.

15. Liu, X.L., L.X. Du, F.P. Lu, X.Q. Zheng and J. Xiao, 2005. Purification and characterization of a novel fibrinolytic enzyme from Rhizopus chinensis12. Appl. Microbiol. Biotechnol., 67: 209-214.

16. EI-Aassar, S.A., H.M. EI-Badry and A.F. Abdel-Fattah, 1990. The biosynthesis of proteases with fibrinolytic activity in immobilized cultures of Penicillium chrysogenum H9. Appl. Microbiol. Biotechnol., 33: 26-30.

17. Kim, J.S., S. Kumar, S.E. Park, B.S. Choi, S. Kim, T.H. Nguyen, C.S. Kim, H.S. Choi, M.K. Kim, H.S. Chun,Y. Park and S.J. Kim, 2006. A fibrinolytic enzyme from the medicinal mushroom Cordyceps militaris. J. Microbiol., 44: 622-631.

18. Pandee, P., A.H. Kittikul, O. Masahiro and Y. Dissara. 2008. Production and properties of a fibrinolytic enzyme by Schizophyllum commune BL23. Songklanakarin J. Sci. Technol., 30: 447-453.

19. Cha, W.S., S.S. Park, S.J. Kim and D. Choi, 2010. Biochemical and enzymatic properties of a fibrinolytic enzyme from Pleurotus eryngii cultivated under solid-state conditions using corn cob. Bioresour. Technol., 101: 6475-6481.

20. Astrup T, Mullertz S. The fibrin plate method for estimating fibrinolytic activity. Arch Biochem 1952; $40: 346-51$

21. Mukesh Kumar D J; Rakshitha R;. Annu M;.Vidhya P. Sharon Jennifer, Sandip Prasad, M. Ravi Kumar and P.T. Kalaichelvan. 2013. Pakistan Journal of Biological sciences, 17 (4):529-234

22. Shilpa H. K, Jeevan G. Ambekar, Siddalingeshwara K. G and Nilima N. Dongre. 2014. An approach on biosynthesis of fibrinolytic enzyme from Aspergillus Sp. Journal of Chemical and Pharmaceutical Research, 6(12): 797-801

23. Usama F Ali. ZM and Ibrahim, Journal of Applied Sciences Research, 2008,4(7), 892-899.

24. Venkatanagaraju E and Divakar G. 2013. International Journal of Pharma Sciences and Research,Vol 4, No 5, 81- 93. 